\title{
Middle East Popular Politics in Gramscian Perspective
}

26 February 2021

\section{Abstract}

This article outlines a theoretical framework for researching popular politics in the Middle East and North Africa. The paper sketches a Gramscian alternative to existing approaches in materialist Marxism, cultural studies, and social movement studies. It aims to think a Gramsci useful to historians, political scientists, sociologists and anthropologists, beyond the common loci of Gramsci scholarship in political theory, comparative literature, and international relations. With a start point in Gramsci's philosophy of praxis, it puts forward a concept of popular politics as a mostly slowmoving, complex and many-layered transformative activity, a form of historical protagonism comprised of a variety of moments, capable of working changes on existing forms of hegemony and founding new social relations. The point is to enable researchers in Middle East Studies to see and research popular politics, carry on a critique of transformative activity, and to inform transformation in the present.

Keywords: popular politics, Gramsci, Middle East Studies, resistance, subaltern social groups, social movements, praxis

\section{Introduction}

This article outlines a theoretical framework for researching popular politics in the Middle East and North Africa, drawing on Gramscian perspectives. While the problematics of popular politics, the question, as the young Gramsci put it, of 'how best to convert the facts of vassalage into the signals of rebellion and social reconstruction', ${ }^{1}$ have traditionally been occluded in Middle East Studies, the post-2011 context, overall, has been more fertile and provocative. The paper sketches a Gramscian alternative to existing approaches in materialist Marxism, cultural studies, and social movement studies. It aims, further, to think a Gramsci useful to historians, political scientists, sociologists and anthropologists, beyond the common loci of Gramsci scholarship in political theory, comparative literature, and international relations. $^{2}$ With a start point in Gramsci's philosophy of praxis, it puts forward a concept of

\footnotetext{
${ }^{1}$ Gramsci, Political Writings (1910-1920), 12.

${ }^{2}$ Laclau and Mouffe, Hegemony and Socialist Strategy; McNally and Schwartzmantel, Gramsci and Global Politics; Sanbonmatsu, The Postmodern Prince; Thomas, Gramscian Moment; Williams, Marxism and Literature.
} 
popular politics as a mostly slow-moving, complex and many-layered transformative activity, a form of historical protagonism comprised of a variety of moments, capable of working changes on existing forms of hegemony and founding new social relations. The point is to enable researchers in Middle East Studies to see and research popular politics, carry on a critique of transformative activity, and to inform transformation in the present.

\section{Popular Politics Occluded and Engaged}

Middle East Studies has not engaged as extensively with questions of popular politics and subaltern activism as might be assumed. (Neo)Orientalism dismisses popular politics in racist, exceptionalist and essentialist terms as 'self-pity', 'Muslim rage', terrorism, resentment, sexual frustration, violence, disorder and threat. ${ }^{3}$ Essentializing and romanticizing the subaltern in the clothes of cultural and religious authenticity has been shown to be problematic in nationalist and Islamist perspectives. ${ }^{4}$ Elitist and hard-power approaches are still common, especially in conventional political science. ${ }^{5}$ Narratives of globalization tend towards determinism and homogenization, and liberal discussions of civil society, human rights, and the public sphere towards a focus on abstracted, middle class, respectable, professionalized, legal, decorous, 'civilized', and non-subaltern practices. ${ }^{6}$ Social movement studies tends not to see or think hegemony and subalternity, and fails to engage with challenges to domination, changing the world, or critical studies of capitalism, state power, race, gender and sexuality. ${ }^{7}$

Critical work also has problems. Materialist Marxism, rising again since the financial crisis of 2008, often suffers from 'mechanistic and fatalistic conceptions of economism'. ${ }^{8}$ Thinking subaltern activism solely in terms of class struggle and capitalism diminishes the vital

\footnotetext{
${ }^{3}$ Burke and Lapidus, Islam, Politics, and Social Movements; Said, Orientalism.

${ }^{4}$ Achcar, Marxism, Orientalism, Cosmopolitanism; Al-“Azm, "Orientalism in Reverse"; Fahmy All the Pasha's Men; Mossallam, "Hekāyāt Sha'b.",

${ }^{5}$ Brownlee, Masoud, and Reynolds, The Arab Spring; Owen, State, Power and Politics.

${ }^{6}$ Keck and Sikkink, Activists beyond Borders.

${ }^{7}$ Tarrow, Power in Movement.

${ }^{8}$ Gramsci, Letters from Prison (Vol II), 169.
} 
importance of body, civil society, culture, and politics. Studies of hegemony, even in Gramscian mode, often emphasize political economy over culture, and/or start from the top down, seeing resistance as an epiphenomenon of dominant tendencies. ${ }^{9}$ Although important research has been carried out, ${ }^{10}$ Subaltern Studies has had less traction in Middle East Studies than in South Asia and Latin America, and has been appropriated less in terms of popular struggle and politics 'from below', and more in terms of power/knowledge and discourse. ${ }^{11}$ Foucauldian approaches around discipline, power/knowledge, the microphysics of power, Orientalism, and gender/sexuality are usually taken up in ways that leave the issue of substantive transformative activity in the shadows. ${ }^{12}$ Or, the critique of Western discourse can drown out the interpretive and historicizing understanding of the struggles and lives of subaltern groups. ${ }^{13}$ In cultural studies, the problematic of signification tends to displace questions of practice, subaltern experience, organization, and strategy.

The popular uprisings of 2011, the Rojava Revolution, and the rapid growth of the BDS movement inter alia, have accompanied some positive changes. The uprisings of 2011 enrolled a new generation in activism, and stimulated the study of non-elite initiatives. Critical and engaged fora such as jadaliyya.com have emerged. Tunisia has hosted the World Social Forum twice. Dissatisfaction with uncritical social movement studies has been registered. ${ }^{14}$ There have been powerful critiques of global civil society, NGOs, international donors, human rights discourses and international law. ${ }^{15}$ Middle East Studies has attracted more interest among progressives generally. ${ }^{16}$ There has been important new work on feminism, gender, sexuality

\footnotetext{
${ }^{9}$ Ayubi, Over-stating the Arab State; Roccu, "Gramsci in Cairo."

${ }^{10}$ Cronin, Subalterns and Social Protest.

${ }^{11}$ Chalcraft, "Of Horses and Ponies," 376-378.

12 Mitchell, Colonising Egypt.

13 Sarkar, "The Decline of the Subaltern."

${ }^{14}$ Gerges, Contentious Politics in the Middle East.

${ }^{15}$ Bhatia, "Social Movements in Authoritarian States."; Challand, Palestinian civil society; Khalili, Heroes and Martyrs of Palestine; Perugini and Gordon, Human Right to Dominate.

${ }^{16}$ Knapp, Flach, and Ayboga, Revolution in Rojava.
} 
and transnationalism, ${ }^{17}$ as well as on resistance, protest and popular politics, including in Gramscian perspective. ${ }^{18}$ Right-wing, populist, misogynist and authoritarian tendencies in countries such as Turkey, Israel and Egypt have sharpened the urgency of questions about popular politics. Gramsci's inter-war Italy, and the rise of fascism in the wake of the biennio rosso of 1918-20, looks more relevant to the contemporary MENA. While 'morbid symptoms' abound, ${ }^{19}$ promising directions in activism and research fertilize the development of new approaches.

\section{The Philosophy of Praxis}

The framework begins with Gramsci's 'philosophy of praxis'. The major premise is that the 'philosophy of praxis' is not materialist Marxism. It is instead an original synthesis of Benedetto Croce on culture, Niccolò Machiavelli on the state, and Karl Marx on capitalism elaborated in Italy in the age of Vladimir Lenin. Out of this synthesis comes Gramsci's core concept of hegemony - the complex, incomplete combination of theory and practice, coercion and consent at work in the realization of activity in a concrete 'historico-political' ${ }^{20}$ formation. Gramsci's synthesis involves unity in diversity, history and theory, base and superstructure, and an interlocking of culture, economy, civil society, and the state. Parsing hegemony involved Gramsci in an original elaboration of concepts of civil society, organic intellectuals, historical bloc, dominant and subaltern social groups, wars of manoeuvre and position, and his great emphasis on 'cultural direction', contradictory consciousness, conceptions of the world, forms of collective will, organization, leadership, and the national-popular. It is sometimes

\footnotetext{
${ }^{17}$ Al-Ali and Tars, "Dialectics of Struggle"; Pinilla, "The female protestor." Tatour, "Domination and Resistance."

${ }^{18}$ Abdelrahman, Egypt's Long Revolution; Alfasi, "Political Agency and the Symbolic Legacy"; Bayat, Revolution without Revolutionaries; Beinin, Workers and Thieves; Beinin and Vairel, Social Movements, Mobilization, and Contestation; Boeddeling, "From Resistance to Revolutionary Praxis"; Chalcraft, Popular Politics; de Lellis, "The Left and the Peasant Question in Egypt"; De Smet, Dialectical Pedagogy of Revolt; ElKahlaoui, "Resisting Urban Modernisation"; Feltrin, "Hammer and the Anvil"; Munif, "The Arab Revolts"; Musallam, "Failure and the politically possible"; Salem, "Critical interventions"; Tripp, Power and the People; Yousfi, Trade Unions and Arab Revolutions.

19 Achcar, Morbid Symptoms.

${ }^{20}$ Gramsci, Letters from Prison (Vol II), 169.
} 
forgotten that hegemony as a living historical activity does not sanctify the status quo, but puts it in a critical, historical light, referencing its incompleteness, for those seeking to transform it via revolutionary praxis and the construction of alternatives. The latter involves 'practicalcritical activity', ${ }^{21}$ a new unification of theory and practice; it implies a 'going to the people', where the latter is understood as the ensemble of subordinated groups. Praxis embraces and actualizes what the young Marx called the 'categorical imperative to overthrow all relations in which man [and woman] is a debased, enslaved, forsaken, despicable being'. ${ }^{22}$ Praxis involves historically-embedded conscious, collective activity challenging subordination and building new social relations, changing the terms of existing form of hegemony and/by ameliorating or eliminating subaltern status. Gramsci's philosophy of praxis is powerful start point for the study of popular politics as transformative activity.

Thinking power, subordination and transformation in terms of hegemony and praxis has a vital importance in Middle East Studies. First, in combining culture, economy, civil society, and the state, this approach responds to Lockman's unresolved challenge to the field: 'to combine due attention to the question of representation with due attention to social and political dynamics, hierarchies of power and historical contexts, and to explore how these domains are intertwined'. ${ }^{23}$ Lockman sought a way beyond the linguistic and deconstructionist excesses of the cultural turn. He sought an approach that could sustain an analysis of material practice, without a return to economistic or deterministic Marxism and/or modernist teleology. Second, Gramscian perspectives have a particular ability to travel because of their rich attention

\footnotetext{
${ }^{21}$ Marx, Theses on Feuerbach (1845), https://www.marxists.org/archive/marx/works/1845/theses/theses.htm (accessed 26 April 2019)

${ }_{22}$ Marx, (Abstract from) The Introduction to Contribution to The Critique Of Hegel's Philosophy Of Right (1844) https://www.marxists.org/archive/marx/works/1844/df-jahrbucher/law-abs.htm (accessed 26 April 2019)

${ }^{23}$ Lockman, Contending Visions of the Middle East, 212.
} 
to history and national context. Gramsci's core concepts, indeed, only make sense when thoroughly historicized. ${ }^{24}$

\section{Subaltern Social Groups}

Gramscian optics imply that the study of popular politics engages, first, with the historical and interpretive understanding of the experiences and situations of subaltern social groups, including workers, peasants, migrants, women, slaves and minorities ${ }^{25}$ 'serial' sets of social subjects, thrown together or dispersed, having in common not a 'fused' or conscious community, but a similarity of fate, and living a situation marked and defined above all by subordination amid a complex and incomplete ensemble of hegemonic structures. ${ }^{26}$ Subordination operates directly and indirectly through cultural speechlessness, embodied social stigma, economic dispossession, and political exclusion. At stake are both objectification and subjectivation: subaltern social groups are defamed, Otherized, misrecognized, and made inarticulate; they are subjectivized by reading and understanding their own situation in terms of a common sense marked by the concepts of ruling and middle classes elaborated and diffused in civil society; they are economically exploited, reified, marginalized, and made dependent, and they are subjected to violent domination. Their very being is riveted to nature: to the primordial, the racialized epidermis, the ethnic, the improvident, the base, the hysterical, the sexually deviant, the exotic, the irrational, and the violent. The subaltern woman, by the standards of the Italian public, writes Gramsci, is enclosed in a 'circuit of nerves, muscles and sensitive skin'; she is 'the female who nurses her newborn and feels . . . a love made up of spasms of the flesh and palpitations of the heart'; or she is the cocotte, a 'slave' in the 'bourgeois family', 'the doll who is the more dear the more stupid she is' ${ }^{27}$ She, in Sartre's

\footnotetext{
${ }^{24}$ Fabio Frosini, "Hégémonie, praxis, traduction: entretien sur Gramsci avec Fabio Frosini" (2 October, 2017) http://revueperiode.net/hegemonie-praxis-traduction-entretien-sur-gramsci-avec-fabio-frosini/ (accessed 24 April 2019).

${ }^{25}$ Green, "Gramsci Cannot Speak," 2.

${ }^{26}$ Gramsci, Selections from the Prison Notebooks, 333.

${ }^{27}$ Antonio Gramsci, Cultural Writings, 71-2.
} 
phrase, 'subordinates her reality as a conscious subject to the Other that she is for Others' ${ }^{28}$ The words and actions of subaltern groups are explained as but the 'expression of a psychophysiological mechanism'. ${ }^{29}$ Like Jews in Arendt's Europe or gay men in Eribon's France, they are by turns 'pariah' or 'parvenu', absent qua group 'from the historical and political arena'. ${ }^{30}$ A subaltern social group, writes Gramsci, is 'deprived of historical initiative', ${ }^{31}$ 'has not yet gained consciousness of its strength, its possibilities, of how it is to develop, and ... therefore does not know how to escape'. ${ }^{32}$ Subaltern history is written in 'fragments' and 'episodes'. As Gramsci writes, 'it never occurs to them [subalterns] that their history might have some possible importance, that there might be some value in leaving documentary evidence of it'. ${ }^{33}$

Subaltern Studies, which has developed into a significant sub-field in its own right since its launch by historians of South Asia in 1978, has done a great deal to establish the diversity, complexity, and historicity of subaltern social groups in the history of South Asia and beyond. ${ }^{34}$ Subaltern optics have been brought to bear, to some extent, in Middle East Studies. Stephanie Cronin captures the main point by defining subaltern social groups in the region as 'a wide range of groups who possess a subordinate social, political, economic and ideological status' ${ }^{35}$ Relevant here are the urban and rural poor, workers, the peasantry, slum dwellers, the unemployed, as well as women, migrants, bandits, gypsies, and slaves. In other research, women dispersed in patrilineal households 'bargaining with patriarchy', ${ }^{36}$ facing state violence

\footnotetext{
${ }^{28}$ Sartre, Saint Genet, 33-4.

${ }^{29}$ Ibid, 588.

${ }^{30}$ Eribon, Insult and the Making of the Gay Self, 348.

${ }^{31}$ Gramsci, Selections from the Prison Notebooks, 396.

32 Ibid., 151.

${ }^{33}$ Ibid., 196.

${ }^{34}$ Chatterjee, The Politics of the Governed; Chaturvedi, Mapping Subaltern Studies; Rodríguez, Latin American Subaltern Studies.

${ }^{35}$ Cronin, Subalterns and Social Protest, 2.

${ }^{36}$ Kandiyoti, "Bargaining with Patriarchy."
} 
in Egypt after $2011,{ }^{37}$ selling sex in colonial Cairo, ${ }^{38}$ or LGBTQ groups in Israel/Palestine, ${ }^{39}$ and workers of many kinds (industrial, peasant, migrant, precarious, domestic, female, marginalized, self-exploiting, squeezed, and survivalist $)^{40}$ have been studied via an interpretive understanding of subaltern situations and experiences. Bayat writes strikingly of subaltern groups in Egypt as those feared as 'the spoilers of public order, as culprits of violence'. ${ }^{41}$ As the Tunisian, Jewish anti-colonial intellectual, Albert Memmi put it in the 1950s, the 'colonised' are those who are immediately punished even if so much as a 'rusty weapon' is discovered among them. ${ }^{42}$

Edward Said, drawing on Gramsci, Foucault, and a broad democratic humanism, understood the situations of Muslims, Arabs and Palestinians, in the diaspora and the region, in terms of how such groups were Otherized and subordinated by the cultural hegemony of Orientalism combined with imperial domination. ${ }^{43}$ Massad has extended such optics, drawing on Gramsci, but especially Foucault, in thinking about the making of Jordanian national identity as an effect of a colonial discourse, ${ }^{44}$ and in studying how males in the Arab world engaged in same-sex practices have been subjected to the missionary activities of a 'gay international' rooted in Euro-American identitarian constructions of sexuality. ${ }^{45}$ Frantz Fanon, the psychiatrist from Martinique, anti-colonial activist, and organic intellectual of Third World and black liberation, explains how the racializing look from the site of the white other on the black epidermis fixed and 'sealed' what would otherwise be a rich dialectic between body and world 'into . . c crushing objecthood' ${ }^{46}$ Many colonized Tunisians, in the same period, sought

\footnotetext{
${ }^{37}$ Agosti, "Female Protestor."

${ }^{38}$ Biancani, Sex Work in Colonial Egypt.

39 Tatour, "Domination and Resistance."

${ }^{40}$ Beinin and Duboc, “A Workers' Social Movement”; Chalcraft, The Invisible Cage; de Lellis, "The Left and the Peasant Question"; Feltrin, "Hammer and the Anvil"; Tucker, Women in Nineteenth Century Egypt.

${ }^{41}$ Bayat, Revolution without Revolutionaries, 203.

${ }^{42}$ Memmi, Colonizer and Colonized, 137.

43 Said, Orientalism.

${ }^{44}$ Massad, Colonial Effects.

${ }^{45}$ Massad, "Re-Orienting Desire."

${ }^{46}$ Fanon, Black Skin, White Masks, 109.
} 
to assimilate to French 'civilization', a concept elaborated and disseminated in civil society by dominant and intermediary groups, via an assimilation process that was torturous, impossible and alienating. ${ }^{47}$ Decades earlier we find critics of imperialism such as the Egyptian Abdallah Al-Nadim (1843-1896) lamenting the way in which 'Orientals' have been made into a 'race . . . created to serve the Europeans', 'reduced to mere employees, planting, harvesting, and manufacturing in order that Europe's ... fortune increase and the power of her royal houses be swelled' ${ }^{48}$

Cronin makes the vital point that subaltern groups are usually erased from historywriting and considered of no account. As Memmi notes: '[t]he most serious blow suffered by the colonized is being removed from history and from the community. Colonization usurps any free role in either war or peace, every decision contributing to his [or her] destiny and that of the world, and all cultural and social responsibility' [emphasis added]'. ${ }^{49}$ The colonized, writes Memmi, is out of the game: 'He [or she] is no way a subject of history any more. Of course, [she, or] he carries its burden, often more cruelly than others, but always as an object' ${ }^{50}$ As Gilsenan's rich ethnography in 'the periphery of the periphery' in North Lebanon shows, male fellahin (peasant) households thought his questions about their genealogy and family history ridiculous, and directed him towards the socially honourable, those worthy of history, the landowners and 'lords' of the region. ${ }^{51}$

The study of hegemonic discourse itself, however, can draw research far from an interpretive understanding of subaltern struggles. A Gramscian perspective insists that we refuse to succumb to the top-down spectralization of the subaltern, and to any potentially abstract and ahistorical reading of 'the subaltern cannot speak', 52 a Gramscian optic enjoins us

\footnotetext{
${ }^{47}$ Memmi, Colonizer and Colonized, 163-70.

${ }^{48}$ Cited in Abdel-Malek, Contemporary Arab Political Thought, 89.

${ }^{49}$ Memmi, Colonizer and Colonized, 135.

${ }^{50}$ Memmi, Colonizer and Colonized, 136.

${ }^{51}$ Gilsenan, Lords of the Lebanese Marches.

52 Spivak, "Can the Subaltern Speak?"
} 
to seize instead upon every trace of subaltern initiative, and to read 'against the grain'. This was certainly the life-long project of the foremost Ottoman labour historian, Donald Quataert, who always insisted that sources existed for those prepared to search. As Gramsci writes, some part of the subaltern group is always 'directive and responsible, ${ }^{53}$ and hegemony is never fully complete or seamless. We are rightly enjoined not to romanticize resistance: we should equally refuse to romanticize power.

In short, Gramscian optics make the interpretive understanding of subaltern social groups and situations fundamental. Such an optic takes us to the heart of understanding how hegemony is variably and historically formulated, how it works, and where its limits are. Even more importantly, this focus is fundamental to grasping the quality, extent and limits of transformative activity itself, given that such activity works changes on subaltern situations and conditions, and this is ultimately the meaning and measure of transformation. The most important critiques, for instance, of Tunisian liberal democracy after 2011, turn on whether it has transformed certain subaltern conditions - in regards to the socioeconomic dispossession of the inhabitants of peripheral regions and the lives of gendered and sexualized minorities. ${ }^{54}$ The first moment in a Gramscian popular politics, then, involves a historicized understanding of subaltern situations and conditions.

\section{Contradictory Consciousness}

The second moment in a Gramscian perspective on popular politics is subaltern sites of contradictory consciousness. This problematic points towards hegemonic incompleteness. Contradictory consciousness has a crucial value as a genuine expression, however fleeting and dimly registered, of contradictions in existing forms of hegemony. It is consciousness torn by the gap between how things and persons are supposed to be in practice and in theory according

\footnotetext{
${ }^{53}$ Gramsci, Selections from the Prison Notebooks, 337.

${ }^{54}$ Allal and Geisser, "Une démocratisation au-dessus de tout soupçon?"
} 
to the dominant hegemony, and how things and persons are experienced in practice and in theory by subaltern social groups. Contradictory consciousness is the contradictory coincidence of two kinds of consciousness in one consciousness. On the one side is a consciousness 'logically affirmed as an intellectual choice', ${ }^{55}$ or 'uncritically absorbed' ${ }^{56}$ a form of consciousness either voluntaristic or doxic, associated with and intertwined with hegemony, dominant worldviews, civil society, capitalism and the state, a consciousness present and structuring as common sense in the life-activity of subaltern social groups; and on the other side is a consciousness which is present, implicit, and intertwined with the lifeactivity, practices (economic, embodied, social, cultural, or political) and experiences of subaltern social groups, a consciousness 'which emerges from the real activity of each man [or woman], which is implicit in his [or her] mode of action' ${ }^{57}$ When contradictory consciousness occurs in the lives of great masses, writes Gramsci, it is not a matter of 'self-deception', bad faith or hypocrisy, but 'the expression of profounder contrasts of a social historical order' ${ }^{58}$

Contradictory consciousness is a double consciousness existing in and rending apart a single subaltern consciousness. It is half-articulate in that it does not in and of itself have a language or a conception of the world, and certainly not a developed politics. It can often be expressed in mixtures of parody, satire, nostalgia, irony, rejection, dissent, and desire of widely varying political significance. ${ }^{59}$ It is not false (as in Vanguardist conceptions), angry (as in Orientalism), or irrational and/or mired in custom and tradition (as in rationalist Jacobinism) but linked to the contradictory structure of life activity and common sense in a given hegemony: it is only incoherent and unsystematic in so far as it expresses the contradictions of social and historical order. In other words, its very incoherence is revealing and vital, rather than simply

\footnotetext{
${ }^{55}$ Gramsci, Selections from the Prison Notebooks, 326.

${ }^{56}$ Ibid., 333.

57 Ibid., 326.

58 Ibid., 327.

${ }^{59}$ Sum, "The Makings of Subaltern Subjects."
} 
wrong or obfuscatory. Contradictory consciousness is not what Gilles Deleuze rightly dismisses as a 'little, private affair', an individual psychological trauma or deviation requiring expert therapy, but a vital dissonance to be elucidated. It is a collective form of un-rest that calls for, and indeed searches out, the act of 'only connect', of articulation.

Contradictory consciousness is bound with up hegemonic contradictions and 'profound' historical contrasts. Gramsci notes, against the insistence of the ruling class, the lack of complete coherence even in ruling conceptions. ${ }^{60}$ The state can also run into a far reaching 'crisis of authority' (i.e. of hegemony), brought about in part by the failings of ruling groups in major undertakings, for which they had previously won or forcibly extracted, mass consent. Here previous patterns of subaltern consent and subjectivation are thrown into disarray. Common sense, furthermore, is not a seamless, singular expression of the dominant worldview: it is 'necessarily fragmentary', ${ }^{61}$ has different vernaculars, regional particulars, social layers, different tendencies, ambiguities, contradictions, and forms of relative autonomy. At the level of capitalism and class, consciousness among factory wage-workers, for instance, of their activity as the production of use-value sustaining and expanding life could be doubled in contradictory fashion with a wage-worker consciousness conceiving their activity as labour power for sale making commodities for the expansion and accumulation of capital.

Gramsci writes highly suggestively of the 'infinity of traces', historical and social deposits left in bodies and culture left over from previous but now defunct forms of hegemony. Such traces could give rise to and form part of contradictory consciousness, part and parcel, for example, of an 'intellectual crisis, wavering between the old and the new, when he [or she] has lost faith in the old, and has not yet come down in favour of the new' ${ }^{62}$ It is also useful to consider how concrete, subordinated individuals are torn between impulses to non-being and

\footnotetext{
${ }^{60}$ Gramsci, Selections from the Prison Notebooks, 342.

${ }^{61}$ Hall, Hard Road to Renewal, 167.

${ }^{62}$ Gramsci, Selections from the Prison Notebooks, 338.
} 
being, to assimilation and to confrontation, between despair and what Robin Kelley calls freedom dreams.

Contradictory consciousness has been under-researched in Middle East Studies. Michael Gilsenan's ethnography, however, a study of violence, narrative and social change among lords, middling strata and peasants in north Lebanon in the decades before the start of the civil war (1975), elaborates on a more or less identical phenomenon in great detail, especially in the final two chapters of his study 'the challenge of work and wages' and 'horsemen on tractors'. Changes in land tenure, growing investment by 'lordly' landowners in the cities, the spread of wage-labour, changing manners and social comportment among landowners and middling strata, new forms of middle class education, and new consumption patterns among the fellahin (peasant households), new meanings of tradition and modernity, and above all the 'imperatives of work' for the poor and the decline of life structured according to social honour, generated huge contradictions in the consciousness of those who felt bound to masculine honour narratives in one sense, but who were also aware that dominant practices no longer conformed to such codes, and wage-labour and the market was increasingly a basic imperative in their own life activities. Gilsenan writes that in such a context, '[t]he gap between act and narrative, social reality and agent's consciousness . . . [is] no longer a matter of individual failure to establish congruence between seeming and being, it . . . [is] a collective experience'. ${ }^{63}$ A more exact definition of contradictory consciousness could hardly be found. Moreover, the expression of such consciousness, as elsewhere, often involved irony, parody, satire, and unlikely dreams, ${ }^{64}$ figures which do not conceal the seriousness and urgency of subaltern experiences of social suffering, dishonour, violence and impoverishment. ${ }^{65}$

\footnotetext{
${ }^{63}$ Gilsenan, Lords of the Lebanese Marches, 303.

${ }^{64}$ Ibid., p. 299.

${ }^{65}$ I have studied various forms of hegemonic contraction and disincorporation, associated with the break-up of sites of articulation and consent in the history of the MENA, including crises of authority (such as 1798, 1948, or 1967), new forms of political exclusion (such as the cancellation of the elections in Algeria in 1991-2), the elite assault on sites of autonomy (such as on seminary, mosque and bazaar in 1970s Iran), the withdrawal of
} 
Perhaps we can, further, read the 'infinity of traces' in the recent protests of male and female slum-dwellers in Morocco, dispossessed by urban 'development' schemes, but who underline their descent from the Guich tribe, and their proud, nineteenth century association with the royal authority of the makhzan. ${ }^{66}$ Edward Said, of course, made the 'infinity of traces' central to his excavation of what it meant to be an 'Oriental' growing up amid British education systems in Egypt and then working in diasporic exile as an Arab Palestinian in the United States. ${ }^{67}$ Such traces could be detected in Palestinian 'memories of revolt' ${ }^{68}$ or in the traditions that informed the consciousness of the Iranian rural poor, and the uses they made of 'mythologized' pasts. ${ }^{69}$ It seems, furthermore, that subaltern consciousness can be made double, by knowledge of the siren song of a Utopian alternative. Few subaltern social groups in MENA history have been completely unaware of religious or lay intellectuals who proclaim from the margins, such as Ali Shari'ati in 1970s Iran, that things might be otherwise. There are also coeval movements and events elsewhere which suggest alternatives to the status quo, such as how Tunisia and Egypt in 2011 were seen in Syria in 2011, or how the Greek war of independence was perceived by Christians on Mt Lebanon in the $1820 \mathrm{~s}$ and $1830 \mathrm{~s},{ }^{70}$ or how a launderer's son from Asyut in the 1940s conceived of the 'workers and peasants revolution' in the Soviet Union. ${ }^{71}$

The study of everyday forms of resistance can also shed light on ways in which contradictory consciousness develops among subaltern social groups. In Syria in the 2000s,

\footnotetext{
socioeconomic provision (such as in Egypt since the 1970s), as well as violations by elites of previously championed forms of legitimacy, such as in Saudi Arabia during 1929-1932, or 1990-1. Chalcraft, Popular Politics, pp. 36-39, 477-78, 487, 541-2. Hegemonic contraction is not here deterministically related to the rise of transformative activity. It instead undermines existing forms of hegemony, generates feelings of dissent and provokes a search for alternatives (p. 377). The concept can help make sense of the emergence of contradictory consciousness amid profound social and historical 'contrasts'.

${ }^{66}$ El-Kahlaoui, "Resisting Modernization."

${ }^{67}$ Said, Orientalism, 25-26.

${ }^{68}$ Swedenberg, Memories of Revolt.

${ }^{69}$ Cronin, Subalterns and Social Protest, 141.

${ }^{70}$ Hilw, Al- 'Ammiyyat Al-Sha 'biyya / Popular Uprisings.

${ }^{71}$ See Al-Shuhada wa-l-Aru' / Testimonies and Opinions
} 
'acting as-if' worked to preserve an outward surface of consent via 'wooden conformity' in Asad's Syria, ${ }^{72}$ and worked to pulverize subjects, who lost their sense of dignity by being forced to say what they did not believe; but also in this conception there are multiple layers of irony, the belief that things could be otherwise, dreams which should not be spoken, but sometimes were. In other cases, the informal economy channels resources and offers protections to the urban poor according to locally-determined rules, networks and norms, undermining 'what Gramsci called the ideological hegemony of the state', ${ }^{73}$ by creating a gap between the informal and the formal, between state rules and local rules, thus provoking a sense of contradiction.

Finally, one can argue that globalization, diaspora, exile politics, migration, refugee flows, travel, and obligatory cultural and linguistic translation can generate a kind of contradictory consciousness - a sense of not being at home when at home, or of being Kharij Al-Makan or 'Out of Place', as in the title of Edward Said's autobiography; or a sense of 'dislocation, dismemberment, and exile'74 as experienced by Syrian labour migrants to Lebanon, who became 'betwixt and between, a stranger, in different ways, to both worlds' ${ }^{75}$ In migrant subjects, travel and translation, one find a certain dismemberment of identity schemas, i.e. a contradictory consciousness of 'travel' as both discovering, learning, and bettering on the one hand, and, on the other, as a loss of organic roots, of authenticity, of links to kith and kin, of frameworks of linguistic and cultural comprehensibility. One might invoke, for instance, the almost robotic isolation and sense of disconnection that Ahdaf Soueif depicts in her main protagonist in the Eye of the Sun when she returns to Egypt from her spell in 'the North'. At stake - at another level - could be the sort of 'self-doubt' that Olivier Roy associates

\footnotetext{
72 Wedeen, Ambiguities of Domination.

${ }^{73}$ Singerman, Avenues of Participation, 271.

${ }^{74}$ Chalcraft, Invisible Cage, 220.

${ }^{75}$ Ibid., 216.
} 
with rootless, de-territorialized, minority Muslims, denuded of stable cultural references. ${ }^{76}$ This sort of contradictory consciousness, whether resolved in rigid Manicheanism, what Dallal in his discussion of Wahhabism strikingly calls a 'grim and narrow theory of unbelief', ${ }^{77}$ or resolved in the dynamic, transnational embrace of polycentric routes (not roots), of hybridity, syncretism, translation and transculturation, ${ }^{78}$ would presumably be a powerful and ramifying feature of the contemporary world.

Contradictory consciousness is Janus-faced. It is in one sense an important feature of subalternity, and as such as a source of weakness. Abdallah Al-Nadim lamented how we 'Orientals' are 'riven with contradictions and capitulations, constantly turning to foreigners for aid' ${ }^{79} \mathrm{He}$ wrote that 'the folly of the Orientals has made them like the logs devoured in a fire so that others may forge metal'. He was searching for a single voice, mutual support, and the arousal of 'slumbering energies' in economic, political and social action. ${ }^{80}$ Rancour and withdrawal can be also associated with contradictory consciousness. ${ }^{81}$ Satire can be a mere safety valve, and everyday resistance but necessity and survivalism. ${ }^{82}$ On the other hand, contradictory consciousness is a moment of incompleteness in the existing hegemony, it signals 'a site of disarticulation ${ }^{93}$ and provokes a practical-critical search for precisely what Al-Nadim sought - in the first instance - a new voice, a new language, a new conception of the world.

\section{Conceptions of the World}

The third key moment in a Gramscian popular politics arguably involves the development of new conceptions of the world, and their articulation, diffusion, and

\footnotetext{
${ }^{76}$ Roy, Globalized Islam.

${ }^{77}$ Dallal, "Islamic Revivalist Thought," 351.

${ }^{78}$ Hall, Fateful Triangle, 8; Islam, Ethics of Travel.

${ }^{79}$ Cited in Abdel-Malek, Contemporary Arab Thought, 92.

${ }^{80}$ Ibid., pp. 90-2.

${ }^{81}$ Such as among Tunisian Islamists in the 1960s, Burgat, Face to Face with Political Islam, 29-31.

${ }^{82}$ Bayat, Street Politics, 8.

${ }^{83}$ Chalcraft, "Counterhegemonic Effects."
} 
appropriation among subaltern social groups. Here there is a passage from the half-articulate to the articulate; from barely comprehensible murmurings of dissent, to a communicable and shared language; from speechlessness to voice; and from dithering to moral 'certitudes' ${ }^{84}$ There is the spread of new standards, such as a standard in which woman, for instance, is seen not as a doll but as 'a human . . . in herself, with her own awareness, her own inner needs, a human personality entirely her own, and the dignity of an independent being, ${ }^{85}$ There is a shift from heterogeneity to some form of unity; from fragmentation and division to new forms of personality, collective soul, and collective identity. Articulation is a key term here. It involves both an expression in language and conception on the one hand, and a joining of two elements previously sundered on the other. ${ }^{86}$ It is a cultural construction, embedded in activity, that overcomes contradictory consciousness through a new form of organized signification. ${ }^{87}$

How are new conceptions elaborated? There is a compilation, out of the contradictions of hegemonic common sense, of an inventory of traces - an act that Gramsci calls the start point of critical consciousness, a start point that was precisely Edward Said's, acting as a diasporic 'Oriental' subaltern, in his seminal critique of Western thinking about the Orient. ${ }^{88}$ There is also ideological criticism. 'What matters', writes Gramsci,

is the criticism to which such an ideological complex is subjected by the first representatives of the new historical phase. This criticism makes possible a process of differentiation and change in the relative weight that the elements of the old ideologies used to possess. What was previously secondary and subordinate, or even incidental, is now taken to be primary - becomes the nucleus of a new ideological and theoretical complex. ${ }^{89}$

\footnotetext{
${ }^{84}$ Gramsci, Political Writings (1921-1926), 171.

${ }^{85}$ Gramsci, Cultural Writings, 71.

${ }^{86}$ Hall, "Postmodernism and Articulation," 45-6.

${ }^{87}$ Cf Mercer in Hall, Fateful Triangle, p. 18.

${ }^{88}$ Said, Orientalism, 25-6.

${ }^{89}$ Gramsci, Selections from the Prison Notebooks, 195.
} 
Such ideological criticism does not happen ex nihilo, but draws on and re-works elements from existing ideologies. It involves intellectuals - specialists in mental labour. The core point here is that such specialists can only elaborate such conceptions successfully if they do so as organic intellectuals, i.e. in an organic way that it is intimately bound up with the practices, consciousness, conditions, and struggles of subaltern social groups.

Studying the spread of new conceptions of the world implies a significant engagement with popular culture, which in turn implies the question of how meanings are re-articulated, organized, and circulated in the 'fortresses' and 'earthworks' of civil society - schools, media, cultural institutions, theatre, film, art, music, religious organizations, political parties and so on. At stake is the entirety of 'cultural direction' in a given hegemony. A whole field of 'cultural studies' is opened up, with the distinctive line of sight in which culture is neither 'the best of what has been thought and said', nor an abstracted, Geertzian tissue of meaning, but involves conceptions of the world imbricated in practices of domination and transformation.

Gramscian perspectives have informed research in Middle East Studies on popular culture and cultural politics since the $1990 \mathrm{~s} .{ }^{90}$ The inextricable involvement of conceptions of the world with revolutionary politics and popular protest has been underlined. Transnational, Leftist and Third Worldist 'mobilising discourse' has been shown to be fundamental to the politics of Palestinian armed struggle. ${ }^{91}$ Revolutionary vision - or the lack of it - arguably played a key role in $2011 .^{92}$ Kurdish post-nationalism has been understood in terms of discursive re-articulation. ${ }^{93}$ Islamism has been read in terms of the development of an alternative form of hegemony. ${ }^{94}$ Yaseen Noorani has done more than anyone to explore the fundamental cultural conditions and grammars of what makes the 'legitimizing ideals' of

\footnotetext{
${ }^{90}$ Especially since Armbrust, Mass culture and modernism in Egypt.

${ }^{91}$ Khalili, Heroes and Martyrs of Palestine. See also Stein and Swedenburg, "Popular Culture, Relational History."

${ }_{92}$ Bayat, Revolution without Revolutionaries.

${ }_{93}$ Gunes, Kurdish National Movement.

${ }^{94}$ Butko, "Revelation or revolution"; Harb and Leenders, "Know thy enemy."
} 
cultural hegemony - nationalist or Islamist - possible in the colonial and modern Middle East. ${ }^{95}$ The place of religion in the public sphere has been studied through Gramscian optics. ${ }^{96}$ And important questions about transnational cultural politics, including the border-crossing politics of rap, have been explored in regards to Palestine's Jil Oslo ${ }^{97}$ and to Tunisia's 2011 uprising. ${ }^{98}$

One dramatic example of the intersection of activism and new conceptions of the world involves the re-making of what it meant to be a Muslim among Shi ${ }^{\circ} \mathrm{a}$ in Iran in the 1970s. The revolutionary conception, as especially elaborated by the activist thinker Ali Shari'ati, and appropriated among broad popular sectors, that to be a Muslim meant to be engaged in a revolutionary struggle for a classless society (tawhid) against injustice and tyranny, foreign and domestic, in the present, and the accompanying transformation of 'Ashura rituals in civil society from quietist mourning ceremonies, into expressions of a revolutionary political and religious struggle, informed and shaped the Iranian revolution. ${ }^{99}$ Here a new conception of the world provided a powerful resolution to forms of contradictory consciousness - around cultural identity, relations to the 'West', authoritarianism, economy and gender. Ali Shari'ati's proposed 'return to self' is powerfully redolent of the 'inventory of traces', involving as it does, in his own words, not a return to a 'mythologized' or 'reactionary past', but a 'return to that particular human self which has been formed throughout history . . . [A]n old person who embodies and personifies those millions of human beings who have lived in many centuries and have experienced changes, revolutions, various cultures, and ideologies. At the present we are that person'. 100

\footnotetext{
${ }^{95}$ Noorani, Culture and Hegemony, 1.

96 Levine and Salvatore, "Transformation of 'Common Sense.",

97 Maira, Jil Oslo.

98 Gana, "Rap and Revolt."

${ }^{99}$ Abrahamian, "'Ali Shariati: Ideologue of the Iranian Revolution"; Akhavi, "Ideology and Praxis of Shi" ism"; Holliday, "Legacy of subalternity."

${ }^{100}$ Ali Shari'ati, What is to be done, 69.
} 
Gramscian perspectives open up a rich critique of culture, cultural politics, and conceptions of the world. An illustration comes from Egypt in the 2000s. Nicola Pratt, drawing on Gramsci, has shown how a popular cultural hegemony - in which national authenticity, heteronormative masculinism, and state sovereignty form the nucleus - worked to shut down queer spaces, disable human rights activism in defence of bodily autonomy, and stifle democratic spaces of pluralism and diversity. ${ }^{101}$ This optic poses vividly the question of critique - on the one hand the question of the meaning and valence of the once anti-colonial but now suppressive conception of national authenticity, and on the other, more sotto voce in this particular intervention, the question of the meaning and potency of human rights practices and conceptions in failing to bring about transformation in regard to the overwhelming stigmatization of queer men. Both questions are urgent in a contemporary moment stuck between liberal global civil society and human rights on the one hand, itself shaped by the narrow, local knowledge-denying ways in 'which various donors conceive of civil society', ${ }^{102}$ and newly fortified and exclusionary right-wing visions of national, religious, and cultural authenticity on the other. A Gramscian perspective indeed, can add a vital dimension to Perugini and Gordon's important critique of human rights. ${ }^{103}$ In Gramscian optics, the cultural absence of the subaltern social groups, contradictory consciousness and organic intellectuals from the elaboration of the content of human rights codes, international law, and UN Conventions is a crucial dimension of the weakness of human rights activism.

\section{Collective Will}

Out of new conceptions of the world, and a new 'culture in common', comes not just a new identity, but a collective will. As Gramsci writes in a famous passage, 'a multiplicity of

\footnotetext{
101 Pratt, "Identity, Culture and Democratization."

102 Challand, "Evolution of Western Aid," 398.

103 Perugini and Gordon, Human Right to Dominate.
} 
dispersed wills, with heterogeneous aims, are welded together with a single aim, on the basis of an equal and common conception of the world [emphasis added]' ${ }^{104}$ Collective will presupposes and is built on conceptions held in common. Articulation, writes Stuart Hall, fashions a new collective will. ${ }^{105}$ Here the transition to transformative politics, and the overlap between culture and politics, is ever more evident. Subaltern social groups, in a process of transformation, discover not just who they are, where they come from, and what they believe, but what they want. In regards to factory workers, an individual, economic-corporate search for better pay and conditions is merged via culture, 'passion' and 'emotion' with the ethicopolitical. ${ }^{106}$ The collective will is vital as the moment in which subordinated, objectified, instrumentalized or subjectivized social groups start to have, and to be capable of having (on the basis of historically particular and organically-formulated conceptions of the world) ends and purposes that are their own. The fourth key moment, then, has to do with the emergence and workings of the collective will.

Gramsci's passages on the factory occupations of August-September 1920, which he found enduringly inspiring, are highly suggestive. He wrote that (as a result of the dereliction of the Italian Socialist Party), the workers 'can rely on no one but themselves. They must, therefore, develop their spirit of initiative: from a disciplined, industrial object they are becoming a responsible subject. They have to create for themselves a collective personality, a collective soul, a collective will [emphasis in original]'. ${ }^{107}$ Gramsci writes of a 'process of inner liberation through which the worker is transformed from executor to initiator, from mass to leader and guide, from brawn to brain and purpose [emphasis in original]'. ${ }^{108} \mathrm{He}$ goes on: 'the worker ... [amid party activity] "discovers" and "invents" original ways of living, collaborates

\footnotetext{
104 Gramsci, Selections from the Prison Notebooks, 349.

${ }^{105}$ Hall, Hard Road to Renewal, 170.

${ }^{106}$ Gramsci, Selections from the Prison Notebooks, 139-40.

107 Gramsci, Political Writings (1910-1920), 345.

108 Ibid., p. 333.
} 
"consciously" in the world's activity, thinks, foresees, becomes responsible, becomes an organizer rather than someone who is organized and feels he forms a vanguard that pushes ahead and draws the mass of the people after it' ${ }^{109}$ The Turin movement, Gramsci wrote, years later, "gave the masses a "theoretical" consciousness of being creators of historical and institutional values [emphasis in the original]'. ${ }^{110}$

The emergence of the collective will, then, is key moment in the shift from a subaltern status of not being 'an historical person, a protagonist' to 'being 'responsible because it [the changed subaltern element] is no longer [only] resisting but an agent, necessarily active and taking the initiative'. ${ }^{111}$ In collective will a subject, a will immediate to itself and acting for itself, is forged. ${ }^{12}$ The collective will unites a collectively articulated desire for change of a certain kind, with some kind of effective protagonism on the ground. The collective will involves an 'operative awareness of historical necessity' and a 'protagonist of a real and effective historical drama'. ${ }^{113}$ Collective will is 'historically necessary' not because of the ripeness of conditions, nor because of a guarantee of success, but because contradictory historical contrasts are irresolvable without it. Inherent in this concept, wherein failure is a possibility, is a drama, with its attendant forms of myth, poetry, art, and passion.

Research in Middle East Studies has referenced the concept of collective will both directly and indirectly. One of the most dramatic recent examples of collective will in the MENA being that expressed and enacted during the uprisings of 2011: 'the people demand to overthrow the regime'. In Egypt this collective will can be read as directly and inextricably linked to the widespread development, above all since September 2000, of broadly disseminated conceptions in which the regime was figured as the key source of oppression.

\footnotetext{
${ }^{109}$ Idem.

${ }^{110}$ Gramsci, Selections from the Prison Notebooks, 198.

${ }^{111}$ Ibid, 336-7.

${ }^{112}$ Cf Sartre, Saint Genet, 587.

${ }^{113}$ Gramsci, Selections from the Prison Notebooks, 130.
} 
Conversely, the lack of demands to end domestic violence in contemporary Egypt, for instance, can be understood in terms of broadly held conceptions of the world in which women are blamed and men excused for masculine domestic violence. Men are not blamed, not because women are congenitally or psychologically timid, or solely because they are beaten into submission, or because domestic violence is a figment of the Islamophobic imagination, but because many women, researchers have found, do not want to blame them. ${ }^{114}$

As elsewhere, the Gramscian perspective opens many avenues for critique. Egypt's labour movement arguably failed in recent times to move beyond economic corporate demands, and thus was unable to join hands with other segments whose demands were ethico-political. ${ }^{115}$ Conversely, it could well be argued that the Muslim Brotherhood in Egypt did not move beyond its moralizing, ethico-political demands, and thus failed to make links with constituencies seeking socioeconomic change. Or, middle class nationalists in Egypt romanticized the subaltern peasantry as a repository of authenticity, ${ }^{116}$ thus enshrining them within an essentialist framework which did not expect them to transform themselves. Other projects of middle class moral, ascetic, or therapeutic 'uplift', such as bourgeois nationalist abolitionism in regard to sex work, ${ }^{117}$ or middle class youth psychology, ${ }^{118}$ invert this pattern by seeking to change only the subaltern through the good graces of social superiors without seeing any value in popular self-activity.

\section{Organization}

The fifth moment involves questions of organization. In Gramsci, in general, consciousness and action march together in a complex, differentiated, dialectical unity. The

\footnotetext{
114 Yount, "Women's Conformity," 43-44.

115 See Beinin and Duboc, "A Workers' Social Movement"; Alexander and Bassiouny, Bread, Freedom, Social Justice.

${ }^{116}$ Gasper, Power of Representation.

${ }^{117}$ Biancani, Sex Work in Colonial Egypt.

${ }^{118}$ El Shakry, "Youth As Peril And Promise," 591-3.
} 
two 'phases' of 'science and action ... are homogeneous and heterogeneous at the same time'. ${ }^{119}$ The status of thought and action in historical protagonism is equal. As Gramsci continues: 'Christ - Weltanschauung, and St. Paul - organiser, action, expansion of the Weltanschauung - are both necessary to the same degree and therefore of the same historical stature'. ${ }^{120}$ In the same passage Gramsci repeats this idea regarding Marx and Lenin, asserting that it is 'stupid and useless' to create a hierarchy between them. Gramsci also writes that those who will the ends must will the means, ${ }^{121}$ which can only include organization, which Gramsci regards as indispensable to distinguish and establish the independence of the subaltern social group, and to express, make concrete in practice, and diffuse the collective will. ${ }^{122}$ The party, Gramsci writes, is the 'historical laboratory' of new forms of consciousness: it works out 'the ethics and the politics corresponding to these conceptions' [i.e. new conceptions produced by intellectuals] and act[s] as it were as their historical 'laboratory'. ${ }^{123}$ Organization is a unifier of theory and practice, and a site of learning: a place where the educator can be educated, and a place where new ethics and social and economic relations can be directly enacted, as in, for instance, the Factory Councils of Turin in 1918-20. Organized collectivity also, through principles of delegation, representation and informed debate, determines the line of collective action to be followed, and engages as a new element on the terrain of civil society.

Gramsci's preferred mode of organization seems to have been a form of 'democratic centralism'. This he saw as the only form in which the critical, political and historical dialectic could function, the essential point of which he expressed in a luminous phrase: the 'critical search for what is equal in the apparent diversity, and distinct and even opposite in the apparent uniformity'. ${ }^{124}$ Democratic centralism encourages in practice autonomy, participation and

\footnotetext{
119 Gramsci, Selections from the Prison Notebooks, 382.

${ }^{120}$ Idem.

${ }^{121}$ Gramsci, Political Writings (1910-1920), 68.

122 Gramsci, Selections from the Prison Notebooks, 334.

123 Ibid., p. 335.

${ }^{124}$ Gramsci cited in Finocchiaro, Gramsci and dialectical thought, 237.
} 
initiative, implying 'an agile and flexible articulation, that would allow the proletarian body to continue to live whatever blows might be inflicted upon it as a whole or on its individual members' ${ }^{125}$ Rules of organizing should not be perpetual but 'realistic and always keeps close to concrete life in perpetual development', reviewing and criticizing past activity and putting out explanatory circulars. ${ }^{126}$ Gramsci carried on a sharp critique of organizations that became co-opted and/or bureaucratized, acting as ends in themselves, as 'bankers of men in a monopoly situation' like the Turin trade unions, ${ }^{127}$ or degenerating into an anarchist and individualist freefor-all, lapsing into spontaneism, 'discontinuity' and 'improvisation', ${ }^{128}$ or losing contact with subaltern social groups by getting 'lost in "private feuds", ${ }^{129}$ or imposing a rigid revolutionary theory on members, or promoting a sole leader. Gramsci envisaged proletarian organization to include political parties, clandestine groups, factory councils, congresses, peasant leagues, newspapers and the media, schools for popular pedagogy and literacy, and cultural institutes.

In Middle East Studies, Gramscian optics on organization have played an important role in delivering a critique of national and international NGOs. ${ }^{130}$ Gramscian perspectives have also informed critiques of revolutionary activism in 2011, the lack of platforms, and the problems with the organizing style of horizontalism, which makes rapid decision-making difficult, can de-moralize participants by tedious proceduralism, is relatively easy to disrupt or hijack, and can suffer from hidden hierarchies. ${ }^{131}$ A Gramscian critique points away from any panacea in everyday modes of resistance by insisting on organization. Bayat has pointed to the lack of organizing in 2011 by activists among mass constituencies. ${ }^{132}$ On the other hand, Gramscian optics can deliver a strong critique of top-down, middle-class, and vanguardist

\footnotetext{
${ }^{125}$ Gramsci, Political Writings (1921-26), p. 7.

${ }^{126}$ Gramsci, Selections from the Prison Notebooks, 196.

127 Gramsci, Political Writings (1921-26), p. 17-18.

${ }^{128}$ Gramsci, Selections from the Prison Notebooks, 196.

${ }^{129}$ Gramsci, Political Writings (1921-26), p. 18.

${ }^{130}$ Abdelrahman, Civil Society Exposed.

${ }^{131}$ Abdelrahman, Egypt's Long Revolution; Bayat, Revolution without Revolutionaries; De Smet, Dialectical Pedagogy of Revolt.

132 Bayat, Revolution without Revolutionaries, 203.
} 
approaches to organization, as Boeddeling's research on the importance of subaltern praxis in the making of the 2011 Tunisian uprising heavily underscores. ${ }^{133}$

\section{Strategy}

The sixth moment in a Gramscian popular politics engages questions of strategy, the development of a line of collective action by organized groups. While organization works changes directly on bodies and material relations, it also is the vehicle determining strategies and tactics for fighting on the terrain of civil society and the state. In regard to the first, Gramsci famously envisaged a long 'war of position', capturing positions in civil society, re-organizing relations of association, and remaking worldviews. In regard to the second, he envisaged a 'war of manoeuvre', a more rapid, decisive and outright confrontation remaking and transforming political society and the state. ${ }^{134}$ The latter, Gramsci indicated, could be prepared by an 'underground war' of clandestine armed preparation. The war of position serves as 'mental preparation' before and in the service of the war of manoeuvre; it also matters after the seizure of state power to avoid counter-revolution and civil war.

These concepts have been usefully put to work in regards to the Muslim Brotherhood in Egypt. Founded in Egypt in 1928 in the wake of the collapse of the Ottoman Caliphate, the Brotherhood sought to make Egypt more properly Muslim and ultimately to bring about an Islamic state. As Kandil has argued, on release from prison under Sadat in the 1970s, down to the 2000s, the Muslim Brotherhood undertook a long war of position. While cultural da'wa involved a proselytizing summons to the 'true Islam', the Brotherhood commenced a long struggle in civil society, among students, in the professional syndicates, in the media, in mosques, businesses, and charitable associations. The Brotherhood engaged with 'political

\footnotetext{
${ }^{133}$ Boeddeling, "From Resistance to Revolutionary Praxis."

${ }^{134}$ Gramsci, Selections from the Prison Notebooks, 194, 334-5; Gramsci, Political Writings (1910-1920), 68; Gramsci, Political Writings (1921-1926), p. 93.
} 
society' through the judiciary, the religious establishment, and running in parties and elections from the 1980s onwards. Militant splinter groups, impatient with this gradualism, developed their own 'war of manoeuvre', confronting the 'near enemy' (the state) with armed attacks, especially in the 1990s. Kandil argues that the lack of a developed 'war of manoeuvre' among the Muslim Brotherhood itself left it without a strategy to confront state power, leaving it vulnerable to repression, which Kandil sees as an inevitable response by the authorities to a successful war of position. ${ }^{135}$ Kandil's study is an important illustration of how Gramscian strategic analytics can be brought to bear on Islamist politics. It raises anew - in a different context to the post-1945 Italy of Palmiro Togliatti - the question of whether or not the war of position tends to shift towards reformism.

\section{Historical Bloc}

The final moment in a Gramscian optic on popular politics engages the question of 'historical bloc'. Gramsci conceives of revolutionary change less in terms of a Leninist single party seizing state power, and more in terms of a rising, alternative bloc of forces in alliance, such as new forms of economic organization (e.g. the Factory Councils), newspapers (such as L'Ordine Nuovo), cultural associations, a revolutionary political party, and armed groups, forces capable of forming a revolutionary bloc, ${ }^{136}$ stitching together base and superstructure in new ways, realizing a new, differentiated unity of theory and practice, and underpinning the realization of an alternative hegemony. ${ }^{137}$ Gramsci did not just blame bourgeois hegemony for the failure of the revolution in Italy: he also criticized the narrowness of the communist historical bloc. ${ }^{138}$

\footnotetext{
${ }^{135}$ Kandil, "Islamizing Egypt?"

${ }^{136}$ Anderson, Antimonies of Antonio Gramsci, 20.

137 Gramsci, Cultural Writings, 42.

138 Togliatti, On Gramsci, 29-65, 174.
} 
The concept of historical bloc can help understand revolutionary change, its limits or failure in the MENA region. It has been argued, for instance, that migrant labour protests on the Arabian peninsula in the 1950s and 1960s, in contrast to those since the later 1970s, posed a meaningful threat to monarchies because of their articulation within a larger, diverse historical bloc, stitched together by radical Arab nationalism. ${ }^{139}$ Likewise, the 'Great revolt' of 1936-39 drew its historical capacity, arguably, not from a sole leadership, but from a 'generative alignment' of diverse forces, a 'radicalized, rebellious and multitudinous formation'. ${ }^{140}$ Conversely, the fragility of the Egyptian revolutionary uprising, D'Aria argues, owed much to the inconsistency of the 'intermediary force', the Muslim Brotherhood, oscillating between support for the military on the one hand, and alliance with the subaltern, revolutionary 'bloc' on the other. ${ }^{141}$

\section{Discussion}

The framework presented above aims to grasp popular politics as a transformative activity, as theory and practice, being and consciousness in becoming, and as changing vastly along the way. The subject of study - conscious activity challenging domination and bringing about post-subaltern social relations - is not static by definition. The framework ranges from the study of subaltern social groups 'trembling in hundreds before a single white man', to the study of those 'able to organize themselves and defeat the most powerful European nations of their day'. ${ }^{142}$ The seven moments outlined above aim to capture within a single framework the diachronic and synchronic diversity inherent in such historical protagonism, allowing for a depth of analytic purchase on distinct moments.

\footnotetext{
${ }^{139}$ Chalcraft, "Monarchy, migration and hegemony."

${ }^{140}$ Anderson, "From Petition to Confrontation," 593.

${ }^{141}$ D'Aria, "Subalternity and Counter-Revolution," 225.

142 James, Black Jacobins, xviii.
} 
Each moment, or 'turning force', in the series of seven presupposes and builds on the prior moment(s). Organization, for instance, cannot exist meaningfully without the collective will that it expresses, nor collective will without a conception of the world. Transformative activity deepens without guarantees, however. Much depends on historical protagonism itself. Lines of causation can also run 'backwards' through the series. Conceptions of the world, for instance, are educated and expanded by organizational and strategic activity. Popular politics here is slow-moving, and multi-dimensional, a 'long labour', with many set-backs, and incremental gains. Such a conception, does not of course preclude the lighting strike, the war of manoeuvre, the moment after many defeats and much preparation, it is declared 'Hic Rhodus, hic salta! Here is the rose, here dance!' ${ }^{143}$

The perspective is not a species of populism, in which a unified and authentic people is betrayed by rulers personified as conspiring or alien elites. Nowhere has any pure category of 'the people' been invoked. Nor, conversely, do these optics posit the reform only of a corrupted/backward subaltern. At stake instead is what Marx embraced as revolutionary practice: the "coincidence of the changing of circumstances and of human activity or selfchanging' ${ }^{144}$ At stake, is the transformation of subaltern social groups and the terms of the existing hegemony. A Gramscian framework enables us to see, write about and engage in 'the genuine mobilization of popular demands and discontents', ${ }^{145}$ what Gramsci called 'mass politics and not merely an adventure by groups claiming to represent the masses'. ${ }^{146}$

\section{Conclusion}

This article has offered the outlines of a Gramscian theoretical framework for studying popular politics in the Middle East and North Africa. The point is to enable researchers to see

\footnotetext{
${ }^{143}$ Marx, The Eighteenth Brumaire of Napoleon Bonaparte (1852) https://www.marxists.org/archive/marx/works/download/pdf/18th-Brumaire.pdf (accessed 15 May 2019)

${ }^{144}$ Marx, Theses on Feuerbach.

${ }^{145}$ Hall, Hard Road to Renewal, 153.

${ }^{146}$ Gramsci, Selections from the Prison Notebooks, 198.
} 
and research transformative activity, to carry on a critique of popular mobilization, and to inform transformation in the present. The article has put forward a concept of popular politics as a slow-moving, complex and many-layered transformative activity, a form of historical protagonism, capable of challenging subordination, working changes on existing forms of hegemony and founding new, post-subaltern social relations. Rooting the framework in Gramsci's philosophy of praxis, the article distinguishes seven, inter-related moments in popular politics: subaltern social groups, contradictory consciousness, conceptions of the world, collective will, organization, strategy and historical bloc. I aim to have illustrated how these concepts can work in Middle East Studies.

The core purpose is to contribute to a Gramscian alternative to dominant approaches, rooted ultimately in either social movement studies, in which challenges to subordination go missing, in materialist Marxism, which continues to be dogged by economism, or in cultural studies, which is problematic for its sometime cultural abstraction. An important aim, further, is to elaborate a Gramscian perspective on popular movements useful for historians, political scientists, sociologists, and anthropologists, at a time when Gramscian optics are more largely developed in political theory, literary criticism and international relations. It also aims at an optic capable of recovering subaltern activism, against the conventional centrality of top-down understandings of hegemony. While drawing much from Subaltern Studies, this article, by returning to Gramsci's work, aims to bring into focus moments of transformative activity that extend far beyond, and strike against, the confines of subordination, exclusion, and speechlessness that conventionally frame the limits of Subaltern Studies itself. The article also aims to think popular politics in a way distinct from conservative scorn, liberal discomfort, Left sectarianism, and right-wing populism, at a moment of danger in the present. Overall, it is hoped that this article will stimulate debate and inspire new and critical research oriented to understanding, conceptualizing and enacting many forms of transformative activity. 


\section{Bibliography}

Abdel-Malek, Anwar. Contemporary Arab Political Thought. Trans. Michael Pallis. London: Zed Books, 1983.

Abdelrahman, Maha. Civil Society Exposed: The Politics of NGOs in Egypt. London: I.B. Tauris, 2004.

Egypt's Long Revolution: Protest Movements and Uprisings. London: Routledge, 2015.

Abrahamian, Ervand. "Ali Shariati: Ideologue of the Iranian Revolution." In Islam, Politics and Social movements, edited by Edmund Burke III and Ira Lapidus, 289-297. Berkeley: UC Press, 1988.

Achcar, Gilbert. Marxism, Orientalism, Cosmopolitanism. London: Saqi Books, 2013. Morbid Symptoms: Relapse in the Arab Uprising. London: Saqi Books, 2016.

Akhavi, Shahrough. "The Ideology and Praxis of Shi'ism in the Iranian Revolution." Comparative Studies in Society and History 25, No. 2 (1983): 195-221.

Al-'Azm, Sadik Jalal. "Orientalism and Orientalism in Reverse." In Orientalism: A Reader, edited by Alexander L. Macfie, 217-38. New York: New York University Press, 2000.

Alexander, Anne and Mustafa Bassiouny. Bread, Freedom, Social Justice: Workers and the Egyptian Revolution. London: Zed Books, 2014.

Al-Ali, Nadje and Latif Tars. "Dialectics of Struggle: Challenges to the Kurdish Women's Movement." LSE: Middle East Centre Paper Series, 2018.

Alfasi, Kawther. "Political Agency and the Symbolic Legacy of Authoritarian Regimes: The Case of Libya." PhD Thesis, University of Warwick, 2018.

Allal, Amin and Vincent Geisser eds. Une démocratisation au-dessus de tout soupçon? Paris: CNRS Éditions, 2018.

Anderson, Charles. "From Petition to Confrontation: The Palestinian National Movement and the Rise of Mass Politics, 1929-1939." PhD diss., NYU, 2013.

Anderson, Perry. The Antinomies of Antonio Gramsci. London: Verso, 2017.

Armbrust, Walter. Mass culture and modernism in Egypt. Cambridge: Cambridge University Press, 1996.

Ayubi, Nazih. Over-stating the Arab State: Politics and Society in the Middle East. London: I. B. Tauris, 1995.

Bayat, Asef. Street Politics: Poor People's Movements in Iran. New York: Columbia University Press, 1997. Revolution without Revolutionaries. Stanford: Stanford University Press, 2017.

Beinin, Joel. Workers and Thieves: Labor Movements and Popular Uprisings in Tunisia and Egypt. Stanford: Stanford University Press, 2015.

Beinin, Joel and Marie Duboc. "A Workers' Social Movement on the Margins of the Global Neoliberal Order, Egypt 2004-2012." In Social Movements, Mobilization, and Contestation in the Middle East and North Africa, edited by Joel Beinin and Frédéric Vairel, Second Edition, 205-227. Stanford: Stanford University Press, 2013.

Beinin, Joel and Frédéric Vairel eds. Social Movements, Mobilization, and Contestation in the Middle East and North Africa. Second Edition. Stanford: Stanford University Press, 2013.

Bhatia, Luke. "Social Movements in Authoritarian States: an analysis of the human rights movement in Bahrain." PhD Thesis, University of Manchester, 2018.

Biancani, Francesca, Sex Work in Colonial Egypt: Women, Modernity and the Global Economy. London: I.B. Tauris, 2018.

Boeddeling, Jann. "From Resistance to Revolutionary Praxis: Subaltern Politics in the Tunisian Revolution.” PhD Thesis, LSE, 2020. 
Brownlee, Jason, Tarek Masoud, and Andrew Reynolds. The Arab Spring: Pathways of Repression and Reform. Oxford: Oxford University Press, 2015.

Burgat, François. Face to Face with Political Islam. London: I.B. Tauris, 2003.

Burke, Edmund III and Ira M. Lapidus eds. Islam, Politics, and Social Movements. Berkeley: University of California Press, 1990.

Butko, Thomas J. "Revelation or revolution: a Gramscian approach to the rise of political Islam." British Journal of Middle Eastern Studies 31, No. 1 (2004): 141-162.

Chalcraft, John. "Counterhegemonic Effects: Weighing, Measuring, Petitions and Bureaucracy in Nineteenth-century Egypt." In Counterhegemony in the Colony and Postcolony, edited by John Chalcraft and Yaseen Noorani, 179-203. London: Palgrave, 2007.

" "Pensée 1: Of Horses and Ponies." International Journal of Middle East Studies 40, No. 3 (2008): 376-378.

The Invisible Cage: Syrian Migrant Workers in Lebanon. Stanford: Stanford University Press, 2009.

"Monarchy, migration and hegemony in the Arabian Peninsula," LSE: Kuwait Programme Papers, No. 12, 2010.

Popular Politics in the Making of the Modern Middle East. Cambridge: Cambridge University Press, 2016.

Challand, Benoît. Palestinian civil society: Foreign donors and the power to promote and exclude. London: Routledge, 2009.

"The Evolution of Western Aid for Palestinian Civil Society: Bypassing Local Knowledge and Resources." Middle Eastern Studies 44, No. 3 (2008): 397-417.

Chatterjee, Partha. The Politics of the Governed: Reflections on popular politics in most of the world. New York: Columbia University Press, 2006.

Chaturvedi, Vinayak ed. Mapping subaltern studies and the postcolonial. London: Verso, 2000.

Cronin, Stephanie ed. Subalterns and Social Protest: history from below in the Middle East and North Africa. London: Routledge, 2008.

Dallal, Ahmad. "The Origins and Objectives of Islamic Revivalist Thought, 1750-1850." Journal of the American Oriental Society 113, No. 3 (1993): 341-59.

D'Aria, Maria. "Subalternity and Counter-Revolution: The Social Drivers of the Egyptian State Transformation." PhD Thesis, University of Edinburgh, 2020.

De Lellis, Francisco. "The Left and the Peasant Question in Egypt: Theoretical Thinking and Political Praxis from Nasser's Agrarian Reforms to 2015." PhD Thesis, L'Orientale, Naples, 2018.

De Smet, Brecht. A Dialectical Pedagogy of Revolt: Gramsci, Vygotsky, and the Egyptian Revolution. Leiden: Brill, 2014.

El-Kahlaoui, Soraya. "Resisting Urban Modernisation: Occupying the land to resist eviction." Paper Presented at LSE, 18 January 2018.

El Shakry, Omnia, "Youth As Peril And Promise: The Emergence Of Adolescent Psychology In Postwar Egypt." International Journal of Middle East Studies 43, No. 4 (2011): 591610.

Eribon, Didier. Insult and the Making of the Gay Self. Trans. Michael Lucey. Durham: Duke University Press, 2004.

Fahmy, Khaled. All the Pasha's Men. Cambridge: Cambridge University Press, 1997.

Fanon, Frantz, Black Skin, White Masks. Trans. Charles Markham. New York: Grove Press, 1967.

Feltrin, Lorenzo. "Between the Hammer and the Anvil: The Trade Unions and the 2011 Arab Uprisings in Morocco and Tunisia." PhD Thesis, University of Warwick, 2018. 
Finocchiaro, Maurice. Gramsci and the history of dialectical thought. Cambridge: Cambridge University Press, 1988.

Frosini, Fabio. "Hégémonie, praxis, traduction : entretien sur Gramsci avec Fabio Frosini" (2 October, 2017) http://revueperiode.net/hegemonie-praxis-traduction-entretien-surgramsci-avec-fabio-frosini/

Gana, Nouri. "Rap and Revolt in the Arab World." Social Text 30, No. 4 (2012): 25-53.

Gasper, Michael. The Power of Representation: Publics, Peasants, and Islam in Egypt. Stanford: Stanford University Press, 2009.

Gerges, Fawaz ed. Contentious Politics in the Middle East: Popular Resistance and Marginalised Activism beyond the Arab Spring Uprisings. New York: Palgrave, 2013.

Gilsenan, Michael, Lords of the Lebanese Marches: Violence and Narrative in an Arab Society. Berkeley: University of California Press, 1996.

Gramsci, Antonio. Selections from the Prison Notebooks of Antonio Gramsci. Edited and trans. by Quintin Hoare and Geoffrey Nowell Smith. London: Lawrence and Wishart, 1971. . Selections from Political Writings (1910-1920). Trans. John Mathews ed. Quintin Hoare. London: Lawrence and Wishart, 1977.

. (1978) Selections from Political Writings (1921-1926) Trans. and ed. Quintin Hoare (London: Lawrence and Wishart).

Selections from Cultural Writings. Edited by David Forgacs and Geoffrey NowellSmith eds., Trans. William Boelhower. London: Lawrence and Wishart, 1985.

Letters from Prison. Vol II. ed. Frank Rosengarten, trans. Raymond Rosenthal. New York: Columbia University Press, 1994.

Green, Marcus. "Gramsci Cannot Speak: Presentations and Interpretations of Gramsci's Concept of the Subaltern." Rethinking Marxism 14, No. 3 (2002): 1-24.

Gunes, Cengiz. The Kurdish National Movement in Turkey: From Protest to Resistance. London: Routledge, 2013.

Hall, Stuart, "On Postmodernism and Articulation: An Interview with Stuart Hall." Lawrence Grossberg, ed. Journal of Communication Inquiry 10, No. 2 (1986): 45-60.

. The Hard Road to Renewal: Thatcherism and the Crisis of the Left. New York: Verso, 1988.

The Fateful Triangle: Race, Ethnicity, Nation. Ed. Kobena Mercer. Cambridge, MA: Harvard University Press, 2017.

Harb, Mona and Reinoud Leenders. "Know thy enemy: Hizbullah, 'terrorism' and the politics of perception." Third World Quarterly 26, No. 1 (2005): 173-197.

Hilw, Yusuf Khattar al-. Al- 'Ammiyyat Al-Sha 'biyya fi Lubnan / Popular Uprisings in Lebanon. Beirut: Dar al-Farabi, 1979.

Holliday, Shabnam J. "The legacy of subalternity and Gramsci's national-popular: populist discourse in the case of the Islamic Republic of Iran." Third World Quarterly 37, No. 5 (2016): 917-933.

Islam, Syed Manzurul. The Ethics of Travel: From Marco Polo to Kafka. Manchester: Manchester University Press, 1996.

James, C.L.R.. The Black Jacobins. First published 1938. London: Penguin, 2001.

Kandil, Hazim, "Islamizing Egypt? Testing the limits of Gramscian counterhegemonic strategies." Theory and Society 40, No. 1 (2011): 37-62.

Kandiyoti, Deniz. "Bargaining with Patriarchy." Gender and Society 2, No. 3 (1988): 274-290.

Keck, Margaret and Kathryn Sikkink. Activists beyond Borders: Advocacy Networks in International Politics. New York: Cornell University Press, 1998.

Khalili, Laleh. Heroes and Martyrs of Palestine: The Politics of National Commemoration. Cambridge: Cambridge University Press, 2007. 
Knapp, Michael, Anja Flach, and Ercan Ayboga. Revolution in Rojava: Democratic Autonomy and Women's Liberation in the Syria Kurdistan. London: Pluto, 2016.

Laclau, Ernesto and Chantal Mouffe. Hegemony and Socialist Strategy: Towards a Radical Democratic Politics. London: Verso, 1985.

Levine, Mark and Armando Salvatore. "Socio-Religious and the Transformation of 'Common Sense' into the Politics of 'Common Good." In Religion, Social Practice, and Contested Hegemonies. Reconstructing the Public Sphere in Muslim Majority Societies, edited by Mark Levine and Armando Salvatore, 29-56. New York: Palgrave Macmillan, 2005.

Lockman, Zachary. Contending Visions of the Middle East: The History and Politics of Orientalism. Cambridge: Cambridge University Press, 2004.

Maira, Sunaina. Jil Oslo: Palestinian Hip Hop, Youth Culture, and the Youth Movement. Tadween, 2013.

Marx, Karl, “(Abstract from) The Introduction to Contribution To The Critique Of Hegel's Philosophy Of Right." (1844) https://www.marxists.org/archive/marx/works/1844/dfjahrbucher/law-abs.htm Theses on Feuerbach (1845) https://www.marxists.org/archive/marx/works/1845/theses/theses.htm . The Eighteenth Brumaire of Napoleon Bonaparte (1852) https://www.marxists.org/archive/marx/works/download/pdf/18th-Brumaire.pdf

Massad, Joseph. Colonial Effects: The Making of National Identity in Jordan. New York: Columbia University Press, 2001.

"Re-Orienting Desire: The Gay International and the Arab World." Public Culture 14, No. 2 (2002): 361-385.

McNally, Mark and John Schwartzmantel. Gramsci and Global Politics: Hegemony and Resistance. London: Routledge, 2009.

Memmi, Albert. The Colonizer and the Colonized. First Published 1957. Trans Howard Greenfeld. Intro Jean-Paul Sartre, New Intro by Nadine Gordimer. London: Earthscan, 2003.

Mitchell, Timothy. Colonising Egypt. Cambridge: Cambridge University Press, 1988.

Mossallam, Alia. “'Hekāyāt Sha'b.' Nasserism, Popular Politics and Songs in Egypt. 19561974." PhD Thesis, LSE, 2012.

Munif, Yasser, "The Arab Revolts: The Old Is Dying and the New Cannot Be Born." Rethinking Marxism 25, No. 2 (2013): 202-217.

Musallam, Fuad. "Failure and the politically possible: Space, time and emotion among independent activists in Beirut, Lebanon." PhD Thesis, LSE, 2016.

Noorani, Yaseen. Culture and Hegemony in the Colonial Middle East. London: Palgrave, 2010.

Owen, Roger. State, Power and Politics in the Modern Middle East. Third Edition. London: Routledge, 2004.

Perugini, Nicola and Neve Gordon. The Human Right to Dominate. Oxford: Oxford University Press, 2015.

Pinilla, Marta. "The female protestor: sexual violence and the making and unmaking of the state in Egypt post January 25, 2011." PhD Thesis, SOAS, 2019.

Pratt, Nicola. "Identity, Culture and Democratization: The Case of Egypt." New Political Science 27, No. 1 (2005): 69-86.

Roccu, Roberto. "Gramsci in Cairo: neoliberal authoritarianism, passive revolution and failed hegemony in Egypt under Mubarak, 1991-2010." PhD Thesis, LSE, 2012.

Rodríguez, Ileana. The Latin American subaltern studies reader. Durham, NC: Duke University Press, 2001. 
Roy, Olivier. Globalized Islam: The Search for a New Ummah. New York: Columbia University Press, 2004.

Said, Edward. Orientalism. London: Penguin, 1978.

Salem, Sara. "Critical interventions in debates on the Arab revolutions: Centring class." Review of African Political Economy 45:155 (2018): 125-134.

Sanbonmatsu, John. The Postmodern Prince: Critical Theory, Left Strategy, and the Making of a New Political Subject. New York: Monthly Review Press, 2003.

Sarkar, Sumit. "The Decline of the Subaltern in Subaltern Studies." In Mapping Subaltern Studies and the Postcolonial, edited by Vinayak Chaturvedi, 300-322. London: Verso, 2000.

Sartre, Jean-Paul. Saint Genet: actor and martyr. First Published 1952. Trans. Bernard Frechtman. Minneapolis: University of Minneapolis Press, 1963.

Shari'ati, Ali. What is to be done: The Enlightened Thinkers and the Islamic Renaissance. Ed. Farhang Rajaee, Foreword John Esposito. Houston: The Institute for Research and Islamic Studies, 1986.

Singerman, Diane. Avenues of Participation: Family, Politics and Networks in Urban Quarters of Cairo. Princeton: Princeton University Press, 1995.

Spivak, Gayatri Chakravorty. "Can the Subaltern Speak?" In Marxism and the Interpretation of Culture, edited by Cary Nelson and Lawrence Grossberg, 271-313. Basingstoke: Macmillan Education, 1988.

Stein, Rebecca and Ted Swedenburg. "Popular Culture, Relational History, and the Question of Power in Palestine and Israel." Journal of Palestine Studies 33, No. 4 (2004): 5-20.

Sum, Ngai-Ling. "The Makings of Subaltern Subjects: Embodiment, Contradictory Consciousness, and Re-hegemonization of the Diaosi in China." Globalizations 14, No. 2 (2017): 298-312.

Swedenberg, Ted. Memories of Revolt. Fayetteville: University of Arkansas Press, 2003.

Tarrow, Sidney. Power in Movement: Social Movements and Contentious Politics. Second Edition. Cambridge: Cambridge University Press, 2012.

Tatour, Lana. "Domination and Resistance in Liberal Settler Colonialism: Palestinians in Israel between the Homeland and the Transnational." PhD Thesis, SOAS, 2017.

Thomas, Peter D. The Gramscian Moment: Philosophy, Hegemony and Marxism. Chicago: Haymarket Books, 2010.

Togliatti, Palmiro. On Gramsci and Other Writings. Ed. Donald Sassoon. London: Lawrence and Wishart, 1979.

Tripp, Charles. The Power and the People: Paths of Resistance in the Middle East. Cambridge: Cambridge University Press, 2013.

Tucker, Judith. Women in Nineteenth Century Egypt. Cambridge: Cambridge University Press, 1985.

Wedeen, Lisa. Ambiguities of Domination: Politics, Rhetoric, and Symbols in Contemporary Syria. Chicago: University of Chicago Press, 1999.

Williams, Raymond. Marxism and Literature. Oxford: Oxford University Press, 1977.

Yount, Kathryn M. "Women's Conformity as Resistance to Intimate Partner Violence in Assiut, Egypt." Sex Roles No. 64 (2011): 43-58.

Yousfi, Hèla. Trade Unions and Arab Revolutions: The Tunisian Case of UGTT. London: Routledge, 2017. 